\title{
ANALISIS KELAYAKAN FINANSIALUSAHA PERIKANAN TAMBAK POLIKULTUR BANDENG-UDANG WINDU
}

\author{
EVA DOLOROSA ${ }^{1}$, MASYHURI ${ }^{2}$, LESTARI $^{2}$, JAMHARI $^{2}$ \\ ${ }^{1}$ Jurusan Sosial Ekonomi Pertanian Fakultas Pertanian Universitas Tanjungpura \\ ${ }^{2}$ Jurusan Sosial Ekonomi Pertanian Fakultas Pertanian Universitas Gadjah Mada
}

\begin{abstract}
The purpose of this researchwas to analyze the financial viability of milkfish-tiger shrimp polyculture in sylvofishery ponds in PemangkatSub District and non sylvofishery ponds in Jawai, and Jawai SelatanSub District, Sambas. The research method was survey with 133 fish farmers as respondents. Financial analysis with the criteria of NPV, IRR, B / C, and sensitivity analyis. The results of thisresearch showed polyculture of milkfish - tiger shrimp in Pemangkat, Jawai, andJawai SelatanSub District are financially feasible. Polyculture ponds in the Pemangkat sub district with the application of sylvofishery by 60:40 patterns (60\% planted of mangroves and $40 \%$ ponds area) provides the highest NPV value of $40,492,764$, net B / C of 1.9, and $39.5 \%$ IRR, with a return on investment for 3.6 years.
\end{abstract}

Keywords: polyculture, milkfish-tiger shrimp, financial analysis, mangrove

\section{PENDAHULUAN}

Indonesia harus mampu melaksanakan pembangunan ekonomi yang berkelanjutan dalam penggunaan sumberdaya alamnya. Walaupun suatu sumber daya alam tergolong dalam sifat yang terus menerus ada dan dapat diperbaharui oleh alam sendiri maupun dengan bantuan manusia, namun penggunaan sumberdaya alam ini seharusnya seefektif mungkin untuk menjamin manfaatnya secara jangka panjang. Salah satu pemanfaatan sumberdaya alam untuk aktivitas perekonomian adalah usaha budidaya perikanan tambak. Sebagian besar usaha budidaya perikanan tambak di Kabupaten Sambas dengan komoditas utama ikan bandeng dan udang windu dilakukan di daerah pesisir

Adanya kebutuhan tinggi akan pemukiman dan peningkatan kegiatan ekonomi seperti permintaan yang tinggi terhadap komoditas perikanan tambak, terjadilah alih fungsi atau konversi daerah pesisir menjadi tambak. Pada waktu relatif singkat, terjadi perubahan lingkungan pesisir dari wilayah mangrove menjadi areal tambak. Sesungguhnya mangrove memiliki berbagai macam manfaat ekonomis dan manfaat ekologis. Secara ekonomis mangrove berperan menyediakan berbagai macam kebutuhan manusia seperti penyedia kayu bakar, bahan bangunan, peralatan rumah tangga serta manfaat non fisik seperti olah raga, rekreasi dan lainnya. Hutan mangrove memiliki manfaat ekologis sebagai perlindungan bagi lingkungan ekosistem daratan dan lautan; berfungsi sebagai daerah pemijahan (spawning grounds) dan daerah pembesaran (nursery grounds) berbagai jenis ikan udang, kerang-kerangan dan spesies lainnya. Selain itu, serasah mangrove (berupa daun, ranting dan biomassa lainnya) yang jatuh di perairan menjadi sumber pakan biota perairan dan unsur hara yang sangat menentukan produktivitas perikanan. Hutan mangrove juga merupakan habitat 
bagi berbagai jenis burung, reptilia, mamalia dan jenis -jenis kehidupan lainnya, sehingga hutan mengrove menyediakan keanekaragaman (biodiversity) dan plasma nutfah (genetic pool) yang tinggi serta berfungsi sebagai sistem penunjang kehidupan.

Terdapat perbedaan model atau jenis tambak di Kabupaten Sambas. Tambak-tambak yang berlokasi di Kecamatan Pemangkat adalah jenis tambak silvofishery atau biasa disebut tambak wanamina dengan sistem empang parit, yaitu tambak untuk budidaya dibuat dalam bentuk parit yang mengelilingi tanaman mangrove. Luasan yang diterapkan di lokasi penelitian adalah pola 60 : 40 (60\% lahan ditanam jenis pohon mangrove dan $40 \%$ untuk lahan tambak) dan pola 50 : 50 (50\% lahan ditanam jenis pohon mangrove dan 50\% untuk lahan tambak), sedangkan di Kecamatan Jawai dan Jawai Selatan adalah jenis tambak non wanamina, tanpa ditanami mangrove.

Secara keseluruhan telah terjadi penurunan produktifitas perikanan tambak yang dapat disebabkan oleh penurunan kuantitas dan kualitas lingkungan mangrove di pesisir sekitar tambak, dan dalam jangka panjang akan mengancam keberlangsungan usaha perikanan tambak rakyat ini, sehingga tujuan penelitian ini menganalisis kelayakan finansial usaha perikanan tambak polikultur bandengudangwindu

\section{METODOLOGI PENELITIAN}

Penelitian dilaksanakan di Kabupaten Sambas, Provinsi Kalimantan Barat. Lokasi penelitian secara purposive ditentukan di tiga kecamatan dan 5 desa yaitu Kecamatan Pemangkat: desa Pemangkat Kota, Kecamatan JawaiSelatan: desa Jelu Air dan desa Jawai Laut, Kecamatan Jawai: desa Sarang Burung Usrat dan desa Sarang Burung Danau.Penentuan lokasi berdasarkan pertimbangan bahwa lokasi ini merupakan sentra produksi perikanan tambak.

Berdasarkan jumlah populasi pada penelitian ini yaitu para petani tambak yang mengusahakan perikanan tambak polikultur bandeng-udang windu dengan pola tambak wanamina 60:40; 50:50 di Kecamatan Pemangkat, dan tambak non wanamina di kecamatan Jawai dan Jawai Selatan. Penentuan respondenpetani tambak diambil secara random sampling berdasarkan pola tambak yang dilakukan petani tambak. Jumlah responden (n) ditentukan dengan menggunakan rumus Slovin (Sevilla, et al, 1993):

$$
\begin{gathered}
\mathrm{N} \\
\mathrm{n}=\mathrm{N}+\mathrm{Ne}^{2} \\
\mathrm{n}=\text { Jumlah sample } \\
\mathrm{N}=\text { Jumlah populasi } \\
\mathrm{e}=\text { Galat yang dapat diterima }(7.5 \%)
\end{gathered}
$$

maka jumlah total responden yang diambil sebanyak 133 petani tambak dengan rincian sebagai berikut: 
Tabel 1. Rincian dari populasi dan sampel/responden

\begin{tabular}{llcc}
\hline No & Pola Tambak & Populasi & Responden \\
\hline 1 & Pola tambak 60:40 Kec. Pemangkat & 20 & 17 \\
2 & Pola tambak 50:50 Kec. Pemangkat & 32 & 27 \\
3 & Pola tambak non wanamina kec. Jawai & 59 & 44 \\
4 & Pola tambak non wanamina kec. Jawai & 60 & 45 \\
& Selatan & & \\
\hline
\end{tabular}

Sumber: Data primer, 2014

Umur proyek diasumsikan selama 10 tahun. Tingkat discount rate yang digunakan merupakan tingkat suku bunga KUR Bank Rakyat Indonesia pada tahun 2013 sebesar 19\%.Analisis kelayakan finansial menggunakan kriteria NPV, Net B/C, IRR, dan Payback Period

Net Present Value (NPV).

NPV atau nilai sekarang bersih adalah jumlah nilai sekarang dari manfaat bersih yang dirumuskan (Gittinger, 1982) sebagai berikut :

$$
N P V=\sum_{t=1}^{n} \frac{B_{t}-C_{t}}{(1+r)^{t}}
$$

Keterangan :

$\mathrm{Bt}=$ Benefit (penerimaan) tahun $\mathrm{t}$

$\mathrm{Ct}=$ Cost (Biaya) tahun $\mathrm{t}$

$\mathrm{R}=$ Discount rate / tingkat bunga

$\mathrm{n}=$ umur proyek

Kriteria pengambilan keputusan usaha perikanan tambak di sekitar kawasan mangrove layak jika Jika NPV > 0, sebaliknya jika NPV adalah negatif maka kegiatan tidak layak dilakukan.

\section{Internal rate of return (IRR)}

IRR merupakan ukuran pengembalian nilai investasi. Untuk mendapatkan nilai IRR digunakan rumus Interpolasi :

$$
\mathrm{IRR}=\mathrm{i} 1+\frac{\mathrm{NPV}^{+}}{\mathrm{NPV}^{+}-\mathrm{NPV}^{-}}\left(\mathrm{i}_{2}-\mathrm{i}_{1}\right)
$$

Keterangan :

i1 = tingkat bunga pertama dimana NPV positif

i2 = tingkat bunga kedua dimana NPV negatif

Kriteria pengambilan keputusan usaha perikanan tambak di sekitar kawasan mangrove layak jika IRR > i

\section{Net Benefit Cost Ratio (Net B/C)}

Pengukuran ini lebih menekankan pada kriteria investasi yang pengukurannya diarahkan pada usaha untuk membandingkan, mengukur serta menghitung keuntungan investasi dari suatu proyek atau usaha. Manfaat dan biaya yang dibandingkan adalah dihitung pada waktu yang sama.

$$
\left.B C R=\frac{\sum\left[\beta t /(1+r)^{t}\right]}{\sum\left[C t /(1+r)^{t}\right.}\right]
$$

Keputusan : Jika BCR $>1 \rightarrow$ layak, Jika BCR $<1 \rightarrow$ tidak layak 
Periode kembali modal (Payback period).

Menghitung lamanya investasi dapat ditutup dengan aliran kas masuk.

$P p=\frac{I_{0}}{A_{b}}$

Keterangan:

$\mathrm{Pp}=$ payback period

Io = investasi awal

$\mathrm{Ab}$ : manfaat bersih rata-rata

Kriteria pengambilan keputusan, jika: nilai Pp < dari umur ekonomis usaha perikanan, maka usaha perikanan layak untuk dilaksanakan.

\section{Analisis Sensitivitas}

Analisis sensitivitas ini perlu dilakukan karena dalam kegiatan investasi, perhitungan didasarkan pada proyek-proyek yang mengandung ketidakpastian tentang apayang akan terjadi di waktu yang akan datang (Gittinger 1986). Menurut Warsito (1986) variabel yang dianggap paling peka dalam pembentukan komponen biaya maupun pendapatan adalah kemungkinan perubahan produksi dan perubahan tingkat suku bunga. Dengan adanya ramalan perubahan pada komponen-komponen tersebut dapat dilihat efek adanya perubahan-perubahan pada indikator keberhasilan proyek yang digunakan. Dalam penelitian ini, adanya perubahan pada faktor atau variable penting dalam usaha perikanan tambak polikultur ini adalah adanya penurunan produksi dan kenaikan biaya pupuk.

\section{HASIL DAN PEMBAHASAN}

Perikanan tambak rakyat di daerah penelitian merupakan tambak ekstensif atau tradisional. Petakan tambak biasanya di lahan pasang surut yang umumnya berupa rawa bakau. Ukuran dan bentuk petakan tambak tidak teratur, menggunakan sumber pakan alami tanpa pakan tambahan buatan, dengan sistem polikultur komoditas bandeng dan udang windu. Budidaya polikultur ini cukup menguntungkan petani tambak, karena bisa memanen dua komoditas sekaligus dalam satu siklus budidaya, sehingga menguntungkan secara ekonomis, dan dari segi teknis pemeliharaan juga lebih mudah dan murah

\section{Perikanan Tambak Wanamina di Kecamatan Pemangkat}

Sentra perikanan tambak di Kecamatan Pemangkat berada di dusun Sei Mas, desa Pemangkat Kota. Para petani tambak menerapkan jenis tambak wanamina, yaitu sistem tumpangsari dengan sebagian lahan ditanami jenis tanaman mangrove seperti bakau, siapi-api, dan lain-lain, dan sebagiannya dibuat tambak untuk usaha budidaya ikan bandeng dan udang windu.

Para petani tambak secara mandiri menanam mangrove di lahan nya dengan bantuan bibit mangrove dan pembinaan dari Dinas Kehutanan, Dinas Kelautan dan PerikananKabupaten Sambas dan Yayasan Mangrove Sambas. Para petani menyadari pentingnya menjaga kelestarian ekologis mangrove untuk mendukung keberlanjutan usaha budidaya bandeng dan udang windu.Petani tambak menerapkan pola 60 : 40 (60\% lahan ditanami jenis-jenis pohon mangrove dan 40\% lahan digunakan sebagai tambak), pola tambak 50 : 50 (50\% lahan ditanami jenis-jenis pohon mangrove dan 50\% lahan digunakan sebagai tambak).Jenis mangrove yang ditanam adalah Bakau (Rhizopporamucronata) dengan jarak tanam adalah $5 \times 5$ meter. Jenis mangrove yang paling sesuai untuk 
dikombinasikan dengan tambak adalah Rhizophora mucronata. Maie et al. (2008) menyebutkan bahwa Rhizophora mucronata memproduksi tanin dari daun mangrove. Tanin berfungsi menjaga ketersediaan nitrogen sebagai penyangga siklus nutrien dalam ekosistem mangrove. Dengan demikian, kandungan nutrisi dalam tambak dengan vegetasi Rhizophora cenderung memiliki kandungan nutrien yang lebih melimpah dibandingkan dengan Avicennia. Tanin juga mengandung banyak protein yang secara bertahap dilepaskan ke lingkungan perairan pada saat siang hari

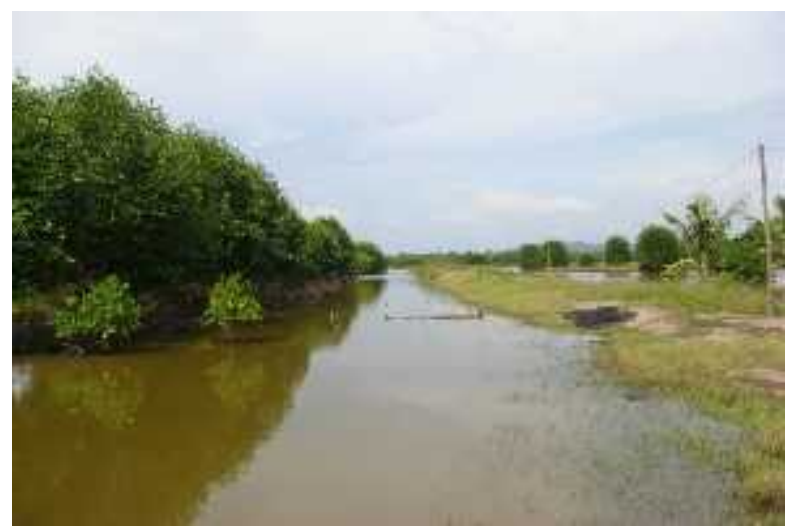

Gambar 1. Tambak Wanamina di Kecamatan Pemangkat Kabupaten Sambas Sumber: Dokumentasi lapangan, 2014

\section{Perikanan Tambak Non Wanamina di Kecamatan Jawai dan Jawai Selatan}

Sentra perikanan tambak di Kecamatan Jawai Selatan adalah desa Jelu Air dan desa Jawai Laut, di Kecamatan Jawai adalah desa Sarang Burung Usrat dan desa Sarang Burung Danau. Jenis tambak yang diterapkan petani tambak di kecamatan Jawai dan Jawai Selatan adalah tambak biasa. Para petani tidak menanam jenis tanaman mangrove di dalam atau sekeliling tambak. Jika pun ada pohon-pohon mangrove adalah sisa dari hutan mangrove sebelum konversi menjadi tambak. Umumnya sekeliling tambak adalah tanaman liar, atau tanaman kebun seperti pisang dan kelapa, terkadang para petani menanami areal lahan sekeliling tambak dengan tanaman cabe, melon, dan berbagai jenis sayuran untuk konsumsi sehari-hari ataupun dijual.

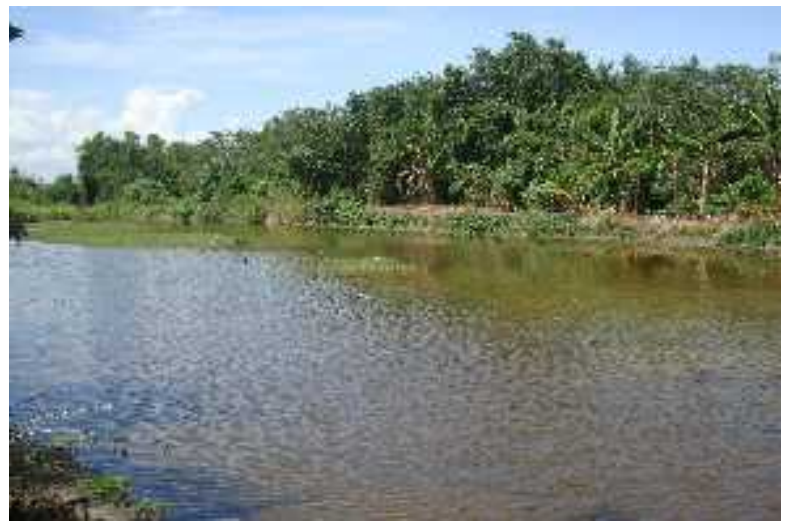

Gambar 2. Tambak Non Wanamina di Kecamatan Jawai dan Jawai Selatan Sumber: Dokumentasi lapangan, 2014 


\section{Arus Penerimaan dan Pengeluaran}

Pada analisis kelayakan usaha perikanan tambak bandeng-udang windu dilakukan perhitungan manfaat dan biaya dengan menggunakan harga pasar yang berlaku di daerah penelitian

\subsection{Arus Penerimaan}

Manfaat atau penerimaan adalah nilai produksi total yaitu hasil penjualan produksi budidaya pembesaran ikan bandeng dan udang windu.Secara rata-rata setiap petani memiliki tambak wanamina seluas 3,7 ha, sedangkan petani tambak di kecamatan Jawai, dan Jawai Selatan memiliki tambak jenis non wanamina dengan rata-rata setiap petani tambak memiliki tambak seluas 3,85 ha yang terdiri dari beberapa kolam tambak dengan berbagai ukuran.Jumlah produksi total tahun pertama adalah Jumlah produksi untuk dua kali musim tebar, sedangkan jumlah produksi tahun kedua sampai tahun ke-sepuluh diasumsikan sama setiap tahunnya.

Hasil produksi yang akan dijual dikelompokkan dalam grade A dan grade B. Untuk ikan bandeng grade A terdiri dari 4-6ekor ikan bandeng untuk setiap kilogramnya, sedangkan grade B terdiri dari 10-12 ekor ikan bandeng setiap kilogramnya. Untuk udang windu grade A terdiri dari 20-25ekor udang windu setiap kilogramnya, sedangkan udang windu grade B terdiri dari 40-50ekor udang windu setiap kilogramnya.

Jumlah produksi dan nilai produksi (penerimaan petani tambak) pada tahun pertama usaha perikanan tambak polikultur seperti tertera pada tabel 2 berikut:

Tabel 2. Jumlah produksi dan penerimaan pada tambak wanamina pola 60:40, pola 50:50, dan tambak non wanamina

\begin{tabular}{|c|c|c|c|c|c|c|c|c|c|}
\hline \multirow[b]{2}{*}{ Jenis Produk } & \multicolumn{3}{|c|}{ Tambak wanamina pola 60:40 } & \multicolumn{3}{|c|}{ Tambak wanamina pola 50:50 } & \multicolumn{3}{|c|}{ Tambak non wnamina } \\
\hline & $\begin{array}{c}\text { Jumlah } \\
\text { (Kg/ha/thn) }\end{array}$ & $\begin{array}{l}\text { Harga } \\
(\mathrm{Rp} / \mathrm{kg})\end{array}$ & $\begin{array}{l}\text { Penerimaan } \\
\text { (Rp/ha/thn) }\end{array}$ & $\begin{array}{c}\text { Jumlah } \\
\text { (Kg/ha/thn) }\end{array}$ & $\begin{array}{l}\text { Harga } \\
(\mathrm{Rp} / \mathrm{kg})\end{array}$ & $\begin{array}{l}\text { Penerimaan } \\
\text { (Rp/ha/thn) }\end{array}$ & $\begin{array}{c}\text { Jumlah } \\
\text { (Kg/ha/thn) }\end{array}$ & $\begin{array}{l}\text { Harga } \\
(\mathrm{Rp} / \mathrm{kg})\end{array}$ & $\begin{array}{l}\text { Penerimaan } \\
\text { (Rp/ha/thn) }\end{array}$ \\
\hline 1 Bandeng Grade A & 690 & 14.647 & 10.106 .471 & 675 & 14.519 & 9.806 .049 & 670 & 14.337 & 9.601 .793 \\
\hline 2 Bandeng Grade B & 272 & 9.941 & 2.700 .437 & 277 & 9.741 & 2.697 .414 & 268 & 9.775 & 2.618 .671 \\
\hline 3 Udang Windu Grade A & 170 & 57.059 & 9.700 .000 & 156 & 55.741 & 8.715 .297 & 140 & 54.910 & 7.687 .416 \\
\hline 4 Udang Windu Grade B & 60 & 32.059 & 1.933 .186 & 58 & 31.111 & 1.811 .574 & 56 & 29.258 & 1.638 .472 \\
\hline 5 Udang/ikan alam & 64 & 15.059 & 969.752 & 60 & 14.926 & 900.220 & 49 & 14.753 & 724.939 \\
\hline 6 bibit mangrove (pohon) & 982 & 400 & 392.941 & 936 & 400 & 374.417 & & & \\
\hline Total & & & 25.802 .786 & & & 24.304 .971 & & & 22.271 .290 \\
\hline
\end{tabular}

Sumber : Analisis Data Primer, 2014

Rata-rata produksi bandeng dan udang windu grade A lebih besar yaitu sekitar $70 \%$ dan grade B sebesar 30\% dari total hasil produksi. Hasil penelitian menunjukkan pada tambak wanamina pola 60:40 yaitu $60 \%$ areal ditanami mangrove dan $40 \%$ sebagai lahan tambak, jumlah hasil produksi bandeng dan udang windu lebih besar dibandingkan dari tambak wanamina pola 50:50 dan tambak non wanamina. Hal ini dapat disebabkan karena kualitas lingkungan perairan tambak wanamina dengan adanya tanaman mangrove lebih baik untuk kehidupan bandeng dan udang windu. Penelitian Musiran (2007) menunjukkan bahwa semakin tinggi luasan mangrove akan menyebabkan semakin tingginya kandungan oksigen terlarut, menurunnya suhu, $\mathrm{PH}$, dan kekeruhan, sehingga membuat lingkungan perairan tambak sesuai untuk tumbuh berkembangnya 
bandeng dan udang windu. Penelitian yang dilakukan oleh Hastuti RB (2011) menyatakan bahwa jenis bandeng (Chanos chanos) yang dibudidayakan pada tambak yang terdapat tanaman jenis Rhizopora dengan makanan organik menghasilkan bandeng dengan berat $155,33 \mathrm{~kg} / 0,5$ ha. Sedangkan bandeng yang dbudidayakan tanpa adanya tanaman mangrove dengan makanan organik memberikan hasil rendah yaitu $70 \mathrm{~kg} / 0,5$ ha dengan ukuran bandeng lebih kecil. Penelitian Poedjirahajoe (2000) membuktikan ikan bandeng yang dipelihara pada tambak wanamina mengalami pertumbuhan rata-rata $100 \mathrm{gr}$ lebih tinggi dibandingkan dengan ikan bandeng yang dipelihara pada tambak non wanamina. Hal ini didukung dengan hasil penelitian Budihastuti, R (2013) menunjukkan bahwa terdapat perbedaan yang nyata terhadap pertumbuhan udang yang dibudidayakan pada tambak yang berbeda. Pertumbuhan udang pada tambak tanpa vegetasi tercatat berkisar antara $4,1-8 \mathrm{~cm}$ dengan rerata 5,9 $\pm 0,7 \mathrm{~cm}$ untuk panjang dan $5-35$ gr dengan rerata $19,5 \pm 6,5$ gr untuk beratnya. Sementara pada tambak dengan vegetasi mangrove jenis Avicennia tercatat berkisar antara 3,9$7,8 \mathrm{~cm}$ dengan rerata $6,3 \pm 0,8 \mathrm{~cm}$ untuk panjang dan $5-60$ gr dengan rerata 29,3 $\pm 13,3$ gr untuk beratnya. Sedangkan pada tambak dengan vegetasi mangrove jenis Rhizophora panjangnya berkisar antara 5,2-8,7 cm dengan rerata 6,8 $\pm 0,7$ cm sedangkan beratnya berkisar antara $25-100$ gr dengan rerata 49,8 $\pm 18,9$ gr

Perikanan tambak rakyat ini juga menghasilkan berbagai jenis ikan dan udang alam. Berbagai jenis ikan alam ini bibitnya berasal dari lingkungan sekitar tambak yang terdapat mangrove yang merupakan tempat berbagai jenis sumber bibit perikanan. Kegiatan pengaliran air dari perairan sekitar tambak untuk menjaga kondisi salinitas tambak akan membawa banyak berbagai macam mahluk hidup yang memasuki perairan kolam tambak kemudian berkembang bersamasama ikan budidaya yaitu bandeng dan udang windu. Hal ini sesuai dengan pendapat Kusmana (1997) yang menyatakan bahwa ekosistem mangrove merupakan sumberplasma nutfah yang cukup tinggi. Selain digunakan untuk konsumsi sehari-hari oleh rumah tangga petani tambak, hasil ikan dan udang alam ini juga dijual di pasar lokal.

Harga jual bandeng dan udang windu yang berasal dari tambak wanamina cenderung lebih tinggi dibanding harga jual dari produksi tambak non wanamina. Jumlah produksi diasumsikan sama setiap tahunnya dengan asumsi lingkungan perairan untuk menunjang kehidupan bandeng dan udang windu dalam kondisi normal, dan padat penebaran benih nener dan benur juga diasumsikan sama, sedangkan harga jual hasil produksi diasumsikan meningkat setiap tahunnya sebesar 7,5\% berdasarkan rata-rata inflasi di Kalimantan Barat sebesar $7,5 \%$. Secara keseluruhan penerimaan hasil produksi usaha perikanan tambak jenis wanamina pola 60:40 dan 50:50 lebih besar dibanding dengan tambak non wanamina, karena hasil produksi dan harga jual yang lebih tinggi.

Nilai sisa merupakan semua biaya modal yang tidak habis digunakan selama umur usaha (Gittinger, 1986). Nilai sisa yang terdapat hingga akhir umur proyek ditambahkan sebagai manfaat proyek. Biaya investasi pada usaha budidaya bandeng - udang windu ini yang memiliki nilai sisa adalah nilai lahan tambakyang diasumsikan meningkat di akhir proyek

\subsection{Arus Pengeluaran}

Pengeluaran dalam usaha budidaya ikan bandeng-udang windu terdiri dari biaya investasi dan biaya operasional. Biaya investasi tambak wanamina 
lebih tinggi dibanding tambak non wanamina, hal ini disebabkan harga lahan di Kecamatan Pemangkat lebih tinggi,dibanding di Kecamatan Jawai dan Jawai Selatan. Selain biaya investasi juga ada biaya reinvestasi yang dikeluarkan oleh petani tambak bila biaya investasi yang dikeluarkan telah habis umur ekonomisnya. Tidak semua biaya investasi mengalami reinvestasi, hanya beberapa biaya saja yang umur ekonomisnya tidak selama umur proyek, yaitu beberapa peralatan usaha budidaya perikanan tambak, seperti pompa air, rumah jaga, dan lain-lain.

Tabel 3. Biaya InvestasiUsaha Perikanan Tambak Bandeng - Udang Windu (Rp/ha/tahun)

\begin{tabular}{|c|c|c|c|c|}
\hline \multirow{2}{*}{ No } & \multirow{2}{*}{ Jenis Biaya } & Wanamina Pola $60: 40$ & Wanamina Pola 50:50 & non wanamina \\
\hline & & Jumlah (Rp/ha) & Jumlah (Rp/ha) & Jumlah (Rp/ha) \\
\hline 1 & Lahan & 9.798 .946 & 9.812 .500 & 9.550 .273 \\
\hline 2 & Pembuatan tambak & 25.000 .000 & 25.000 .000 & 25.000 .000 \\
\hline 3 & Pompa air & 489.458 & 450.000 & 320.454 \\
\hline 4 & Rumah jaga & 3.275 .602 & 3.041 .667 & 2.099 .958 \\
\hline 5 & Kendaraan & 3.934 .488 & $3.447,917$ & 2.108 .358 \\
\hline 6 & Cangkul & 79.819 & 70.938 & 61.214 \\
\hline 7 & Parang & 80.949 & 78.125 & 58.463 \\
\hline 8 & Jaring & 346.386 & 283.333 & 273.835 \\
\hline 9 & Fiber & 436.747 & 433.333 & 447.291 \\
\hline 10 & Ember & 74.360 & 64.271 & 58.421 \\
\hline & Total Biaya Investasi & 43.516 .755 & 42.682 .083 & 39.978 .266 \\
\hline
\end{tabular}

Sumber : Analisis Data Primer, 2014

Komponen input antara lain pupuk, bibit bandeng (nener) dan udang windu (benur), tenaga kerja.Pada tabel 4berikut terlihat penggunaan komponen input pada tambak non wanamina secara rata-rata lebih banyak dibanding pada pola tambak 60:40 dan pola 50:50. Kebutuhan bibit benur dan nener lebih banyak dalam tambak non wanamina. Tingkat mortalitas bibit pada tambak wanamina cenderung lebih rendah, karena lingkungan perairan tempat hidup nener dan benur dipengaruhi oleh sistem perakaran pada berbagai jenis tanaman mangrove yang berada di sekitar tambak, dan mangrove dapat memelihara kualitas air, menyerap $\mathrm{CO} 2$, dan penghasil $\mathrm{O} 2$ yang relatif tinggi dibanding tipe hutan lain (Kusmana, 1997). 
Tabel 4. Jumlah komponen inputUsaha Perikanan Tambak Bandeng - Udang Windu

\begin{tabular}{|c|c|c|c|c|c|}
\hline No & Komponen input & satuan & Wanamina Pola 60:40 & Wanamina Pola 50:50 & non wanamina \\
\hline 1 & Bibit bandeng (nener) & ekotha & 9.017 & 10.906 & 12.138 \\
\hline 2 & Bibit udang windu (benur) & ekor/ha & 9.319 & 11.513 & 13.109 \\
\hline 3 & Pupuk urea & kgha & 139 & 217 & 250 \\
\hline 4 & Pupuk TSP & kgha & 70 & 109 & 115 \\
\hline \multirow[t]{2}{*}{5} & Vitamin: ursal & bungkusha & 4.1 & 6,0 & 10,5 \\
\hline & Vitamin: raja bandeng & bungkus/ha & 3,2 & 5,4 & 6,9 \\
\hline \multirow[t]{3}{*}{6} & Pestisida anorganik: herbisida & liter/ha & 2,2 & 2,4 & 4,0 \\
\hline & Pestisida anorganik: fungisida & literifha & 0,4 & 1,3 & 1,6 \\
\hline & Pestisida anorganik: insektisida & liter/ha & 1,1 & 1,4 & 2.7 \\
\hline 7 & Bahan bakar & liter/ha & 118 & 140 & 145 \\
\hline 8 & Tenaga kerja persiapan lahan & HOK & 10 & 10 & 10 \\
\hline 9 & Tenaga kerja penebarun/pemeliharaan & HOK & 82 & 86 & 82 \\
\hline 10 & Tenagu kerja panes & HOK & 8 & 5 & 7 \\
\hline 11 & Perbaikan tambak & Rp/ha & 450.000 & 450.000 & 450.000 \\
\hline 12 & Pemeliharaan mangrove & Rppha & 200.000 & 200.000 & $\cdot$ \\
\hline 13 & PBB & Rp/ha & 500.000 & 500.000 & 500.000 \\
\hline
\end{tabular}

Sumber: Analisis data primer, 2014

Berdasarkan hasil pengamatan dan wawancara dengan petani tambak dan penyuluh, padat tebar rata-rata per ha berbeda-beda, untuk pola tambak $60 ; 40$ adalah jumlah benih bandeng (nener) sebanyak 9.017 ekor/ha dan benih udang (benur) 9.319 ekor/ha. Untuk pola tambak 50;50, jumlah nener 10.906 ekor/ha dan benur 11.513 ekor/ha, sedangkan tambak non wanamina jumlah rerata nener yang ditebar adalah sekitar 12.138 ekor/ha dan benur 13.109 ekor/ha

Hasil penelitian Kholifah, U et al (2008)padat tebar ikan bandeng 10 ekor/m3 dan udang windu 20 ekor/m2, sedangkan untuk aplikasi di lapangan untuk mendapatkan hasil yang maksimal lebih baik menggunakan padat tebar untuk ikan bandeng $25 \mathrm{ekor} / \mathrm{m} 3$ atau setara dengan 25,000 ekor/ha dan udang windu 20.000 ekor/ha. Syahid et al (2006), menyatakan bahwa kepadatan benih udang yang terlalu padat menyebabkan terjadinya variasi kematian benih yang berbeda-beda, sebagai akibat dari adanya sifat kanibal dan persaingan tempat. Ruang gerak karena adanya padat penebaran secara langsung tidak berpengaruh terhadap kelangsungan hidup ikan bandeng, karena ikan bandeng tidak mempunyai sifat kanibal terhadap lainnya, dan juga ikan bandeng merupakan jenis ikan yang suka berkelompok dalam mencari makanan walaupun dalam jumlah yang tidak begitu besar. Lain halnya dengan udang windu padat penebaran secara langsung berpengaruh terhadap kelangsungan hidup, karena udang windu mempunyai sifat kanibal terhadap lainnya (Tjoronge, 2005). Ikan bandeng dan udang windu memiliki habitat hidup dan kebiasaan makan yang berbeda. Ikan bandeng pada stadia gelondongan hidupnya di kolom perairan yang menyebabkan pergerakkannya luas, aktif kedasar perairan untuk mencari makanan (klekap dan plankton) pada siang hari dengan mengandalkan kemampuan penglihatannya. Sedangkan udang windu stadia gelondongan hidupnya di dasar perairan yang pergerakkannya dipengaruhi oleh luasan lahannya dan adanya pergerakan ikan bandeng untuk mencari makanan didasar sehingga mempengaruhi ruang gerak udang windu 
Kebutuhan pupuk urea dan TSP lebih rendah pada tambak wanamina, dalam tinjauan siklus biomassa, tanaman mangrove memberikan masukan unsur hara terhadap ekosistem air. Sumber makanan utama bagi organisme air di daerah mangrove adalah dalam bentuk partikel bahan organik (detritus) yang dihasilkan dari dekomposisi serasah mangrove (seperti daun, ranting dan bunga). Selama proses dekomposisi, serasah mangrove berangsur-angsur meningkat kadar proteinnya dan berfungsi sebagai sumber makanan bagi berbagai organisme di dalamnya.Primavera dan Esteban (2008) menyebutkan bahwa tanaman mangrove berfungsi sebagai penyedia makanan bagi ikan dan udang. Sementara peran kimia mangrove adalah sebagai penyerap bahan pencemar, penyuplai bahan organik dan sumber nutrien (Pramudji, 2002).

Biaya operasional adalah semua biaya yang dikeluarkan setiap tahunnya selama masa produksi, yang terdiri dari biaya variabel dan biaya tetap. Biaya operasional pengelolaan wanamina lebih rendah dibandingkan dengan tambak non wanamina, hal ini disebabkan jumlah input bibit, pupuk, pestisida, dan lainnya yang digunakan oleh petani tambak wanamina lebih sedikit, sehingga biaya yang dibutuhkan juga cenderung lebih rendah. Biaya pestisida anorganik pada tambak tanpa tanaman mangrove lebih tinggi, hal ini disebabkan tambak yang terbuka bebas lebih rentan terhadap serangan penyakit seperti jamur, dan hama lainnya. Pestisida yang dibutuhkan tidak terlalu banyakdalam tambak wanamina untuk memberantas hama pengganggu kehidupan bandeng dan udang. Hal ini didukung dengan Vaipasha et al. (2007) menyebutkan bahwa fungsi mangrove dalam tambak wanamina berfungsi sebagai biofilter bagi buangan tambak. Shimoda et al. (2006) menyebutkan bahwa salah satu peran mangrove dalam kegiatan budidaya tambak adalah sebagai biofilter, meskipun sebenarnya masih ada jenisjenis biofilter lain yang dapat digunakan. Fungsi biofilter dalam budidaya tambak adalah untuk mengurangi beban pencemar yang akan dibuang ke perairan (sungai atau laut), sehingga kegiatan budidaya yang dilakukan akan lebih berkelanjutan. 
Tabel 5. Biaya Operasional Usaha Perikanan Tambak Bandeng - Udang Windu (Rp/ha/thn)

\begin{tabular}{|c|c|c|c|c|}
\hline \multirow{2}{*}{ No } & \multirow{2}{*}{ BIAYA OPERASIONAL } & \multirow{2}{*}{$\frac{\text { Wunamina Pola 60:40 }}{\text { Jumlah (Rp/hathn) }}$} & \multirow{2}{*}{$\frac{\text { Wanamina Pola 50:50 }}{\text { Jumlah (Rp/ha/thn) }}$} & \multirow{2}{*}{$\frac{\text { non wanamina }}{\text { Jumlah (Rp/hathn) }}$} \\
\hline & & & & \\
\hline & BIAYA VARIABEL & & & \\
\hline 1 & Bibit bandeng (nener) & 303.991 & 377.823 & 435.060 \\
\hline 2 & Bibit udang winda (benur) & 478.445 & 603.167 & 683.276 \\
\hline 3 & Pupuk urea & 250.753 & 390.000 & 454.231 \\
\hline 4 & Pupuk TSP & 151.638 & 242.625 & 275.080 \\
\hline 5 & Vitamin & 242.922 & 382.813 & 561.436 \\
\hline \multirow[t]{3}{*}{6} & Pestisida anorganik & 316.246 & 579.271 & 847.726 \\
\hline & Jumlah Biaya variabel & $1.743,995$ & 2.575 .698 & 3.256 .809 \\
\hline & BLAYA TETAP & & & - \\
\hline 7 & Bahan bakar & 766.002 & 910,000 & 942.500 \\
\hline 8 & Tenaga kerja persiapan lahun & 677.334 & 720.417 & 753.392 \\
\hline 9 & Tenaga kerja penebaran/pemeliharaan & 5.732 .304 & $6.037,500$ & 6.064 .416 \\
\hline 10 & Tenaga kerja panen & 583.773 & 631.458 & 507.242 \\
\hline 11 & Perbaikan tambak & 450.000 & 450.000 & 450.000 \\
\hline 12 & Pemeliharaan mangrove & 200.000 & 200.000 & \\
\hline \multirow[t]{3}{*}{13} & PBB & 500.000 & 500,000 & 500.000 \\
\hline & Jumlah Biaya Tetap & 8.909 .413 & $9.449,375$ & 9.217 .550 \\
\hline & TOTAL BIAYA OPERASIONAL & 10.653 .407 & 12.025 .073 & 12.474 .359 \\
\hline
\end{tabular}

Sumber : Analisis Data Primer, 2014

Tenaga kerja penebaran/pemeliharan pada usaha perikanan tambak polikultur ini memerlukan biaya yang paling besar diantara komponen biaya tenaga kerja lainnya. Hal ini disebabkan kegiatan pemeliharaan terus-menerus dilakukan setiap hari oleh petani tambak yang memerlukan waktu paling lama dibanding tahapan kegiatan budidaya lainnya yaitu kurang lebih selama 2 musim tebar atau 8 bulan periode budidaya. Kegiatan pemeliharaan antara lain mengontrol kualitas air, melakukan penggantian air jika kondisi air kurang baik dengan membuka menutup pintu air tambak yang memanfaatkan pasang surut, mengecek ketersediaan pakan alami, melakukan pemupukan susulan jika kondisi pakan alami kurang atau kualitasnya rendah, mengecek perkembangan benih nener dan benur, monitoring hama dan penyakit, dan lain-lain

\section{Kelayakan Finansial Usaha Perikanan Tambak Bandeng - Udang Windu}

Hasil perhitungan kelayakan finansial usaha Budidaya Bandeng - Udang Windu pada tingkat suku bunga dasar kredit (SBDK) kredit mikro dari BRI sebesar $19 \%$ / tahun, seperti pada tabel 6. berikut:

Tabel 6. Kelayakan Finansial Usaha Perikanan Tambak Bandeng - Udang Windu

\begin{tabular}{llrrr}
\hline No & Kriteria Investasi & Wanamina Pola $60: 40$ & Wanamina Pola $50: 50$ & non wanamina \\
\hline 1 & NPV & 40.942 .764 & 25.736 .796 & 15.180 .587 \\
2 & Net B/C & 1,9 & 1,6 & 1,4 \\
3 & IRR & $39,5 \%$ & $32,4 \%$ & $27,8 \%$ \\
4 & Payback Period & 3,6 & 4,7 & 4,7 \\
\hline
\end{tabular}

Sumber : Analisis Data Primer, 2014

Berdasarkan hasil analisis finansial untuk usaha perikanan tambak dengan tingkat suku bunga 19\% sesuai suku bunga kredit mikro BRI tahun 2013, usaha padasemua jenis tambak diperoleh nilai NPV $>1$, dan Net B/C $>1$, yang 
memenuhi kriteria kelayakan investasi secara finansial. Hasil ini menunjukkan nilai sekarang dari pendapatan selama 10 tahun yang akan memperoleh keuntungan sebesar Rp. 40.942.764,-pada tambak wanamina pola 60:40 dan Rp. 27.736.796,- pada tambak wanamina pola 50:50. Hasil terkecil pada tambak non wanamina sebesar Rp. 15.180.587,-. Hal ini dikarenakan biaya operasional terutama bibit nener dan benur, serta biaya pupuk, vitamin, pestisida lebih tinggi dibanding pada tambak wanamina, sedangkan hasil produksi bandeng dan udang windu lebih rendah dibanding hasil produksi pada tambak wanamina. Hasil penelitian ini sesuai dengan penelitian yang dilakukan oleh Mardiyati (2004) menunjukkan bahwa budidaya tambak dengan sistem wanamina memberikan keuntungan yang lebih tinggi dibandingkan dengan tambak non wanamina.

Nilai IRR masing-masing sebesar $39,5 \% ; 32,4 \%$, dan $27,8 \%$ yang berarti lebih besar dari discount rate yang berlaku. Pada net $\mathrm{B} / \mathrm{C}$ pada usaha ini dengan pola 60:40 adalah sebesar 1,9 yang berarti setiap pengeluaran sebesar satu rupiah pada yang dikeluarkan selama umurproyek mampu menghasilkan manfaat bersih sebesar 1,9 rupiahdan usaha ini layakuntuk dilaksanakan.

Berdasarkan semua kriteria investasi tersebut usaha perikanan tambak rakyat polikultur dengan komoditas bandeng dan udang windu saat ini masih layak untuk dilakukan. Sedangkan payback period atau waktu pengembalian modal pada usaha perikanan tambak wanamina pola 60:40 adalah yang tercepat yaitu dengan nilai 3,6 tahun yang berarti pengembalian investasi adalah sekitar 43 bulan.

\section{Analisis sensitivitas}

Hasil wawancara dengan para petani tambak, yang sering mempengaruhi menurunnya pendapatan petani adalah penurunan produksi bandeng dan udang windu, akibat dari terjadinya perubahan lingkungan yang menyebabkan serangan hama dan penyakit. Berdasarkan hal tersebut, analisis sensitivitas dilakukan dengan melakukan beberapa skenario, yaitu 1) skenario pesimis dengan asumsi penurunan jumlah produksi sebesar $40 \%$ untuk ikan bandeng, dan penurunan produksi $60 \%$ untuk udang windu; 2) skenario optimis peningkatan produksi bandeng sebesar $20 \%$ dan udang windu sebesar $10 \%$, yaitu bila petani mampu mengelola tambak dengan baik dan lingkungan perairan mendukung pertumbuhan dan perkembangan bandeng dan udang windu; 3) penggunaan nilai pengganti (switching value) sampai memperoleh nilai NPV yang mendekati nol, B/C mendekati 1, dan IRR mendekati discount rate.

Analisis sensitivitas juga dilakukan dengan melihat apabila meningkatnya komponen biaya input yang paling sensitive yaitu bila terjadi kelangkaan pupuk bersubsidi yang mengharuskan petani untuk membeli pupuk non subsidi dengan harga lebih tinggi, sedangkan input bibit nener dan benur cukup tersedia dan harga beli oleh petani cukup konstan. Analisis switching value untuk melihat seberapa besar peningkatan biaya operasional yang diperbolehkan sehingga usaha perikanan tambak polikultur ini tidak mengalami kerugian. Harga jual hasil produksi diasumsikan normal dengan adanya peningkatan harga jual setiap tahun sebesar 7,5\% yaitu rata-rata inflasi yang terjadi di wilayah penelitian.

Analisis sensitivitas dengan skenario pesimis berdasarkan hasil pengamatan dan wawancara dengan petani tambak dan penyuluh di lokasi penelitian, yaitu penurunan produksi oleh kematian bandeng yang bisa mencapai $40 \%$ dan kematian udang windu mencapai $60 \%$, yang mengakibatkan kerugian 
yang besar. Hasil analisis sensitivitas bila terjadi penurunan hasil produksi bandeng dan udang windu masing-masing sebesar $40 \%$ dan $60 \%$, menunjukkan bahwa usaha perikanan tambak rakyat ini menjadi tidak layak ditinjau dari semua kriteria investasi. Kerugian terbesar terjadi pada tambak non wanamina yang berlokasi di Kecamatan Jawai dan Jawai Selatan dengan nilai NPV (42.988.366)

Hasil analisis sensitivitas usaha budidaya polikultur bandeng-udang windu dapat dilihat pada tabel 7. berikut:

Tabel 7. Analisis Sensitivitas Penurunan dan Kenaikan Produksi Bandeng Pada Analisis Finansial Usaha Perikanan Tambak Bandeng - Udang Windu

Kriteria Investasi Wanamina Pola 60:40 Wanamina Pola 50:50 non wanamina Penurunan jumlah produksi bandeng $40 \%$, udang windu $60 \%$

\begin{tabular}{lcrc}
\hline NPV & $(28.361 .243)$ & $(38.741 .756)$ & $(42.988 .366)$ \\
Net B/C & 0,3 & 0,1 & 0,1 \\
IRR & $4,1 \%$ & $8,6 \%$ & $9,8 \%$ \\
PP & 12,1 & 12,2 & 12,2 \\
\hline Kenaikan jumlah produksi bandeng $20 \%$, udang windu $10 \%$ & & \\
\hline NPV & 58.935 .852 & 46.474 .607 & 33.916 .119 \\
Net B/C & 2,4 & 2,1 & 1,8 \\
IRR & $46,5 \%$ & $42,4 \%$ & $38,6 \%$ \\
PP & 3,6 & 3,5 & 3,5 \\
\hline
\end{tabular}

Sumber : Analisis Data Primer, 2014

Penurunan produksi sering diakibatkan oleh matinya bandeng, udang windu, atau ikan dan udang lainnya di dalam tambak. Kematian dapat disebabkan oleh adanya hama dan penyakit yang menyerang ikan budidaya yang bisa berasal dari jamur, parasit, bakteri maupun virus. Hama dan penyakit ikan biasanya muncul dan menyerang ikan budidaya apabila kondisi lingkungan perairan berubah ekstrim seperti; perubahan temperature,struktur $\mathrm{pH}$,kesadahan, atau salinitas air yang sangat ekstrim, dan berbagai perubahan parameter air lainnya yang sangat ekstrim sehingga berpengaruh terhadap keseimbangan proses metabolisme pada tubuh ikan dan udang windu yang akan menyebabkan menurunya daya tahan tubuh ikan dan akhirnya menjadi lemah, dan pada kondisi tersebut berbagai jenis penyakit dapat dengan mudah menyerang bandeng dan udang windu yang sedang budidayakan.

Skenario optimisis dengan adanya kenaikan jumlah produksi bandeng sebesar $20 \%$ dan udang windu sebesar $10 \%$ adalah berdasarkan pengalaman para petani tambak dan penyuluh di lokasi penelitian yang menyatakan bila cuaca baik, lingkungan perairan sesuai dengan kebutuhan hidup bandeng dan udang windu, maka bibit nener dan benur akan banyak yang hidup dan dapat berkembang dengan baik. Peningkatan hasil produksi akan menghasilkan penerimaan peatani tambak menjadi dua kali lipat dari biasanya, yaitu tambak pola 60:40 ; pola 50:50; dan tambak non wanamina akan menghasilkan nilai NPV masing-masing sebesar 58.935.852; 46.474.607 dan 33.916.119 Nilai B/C dan IRR juga menunjukkan bahwa usaha perikanan tambak rakyat ini layak. 
Analisis sensitivitas dengan menggunakan nilai pengganti (switching value) sampai memperoleh nilai NPV yang mendekati nol, Net B/C mendekati nilai 1 , dan IRR mendekati nilai discount factor.

Tabel 8. Hasil Analisis Sensitivitas Switching Value penurunan produksi pada Analisis Finansial Usaha Perikanan Tambak Bandeng - Udang Windu

\begin{tabular}{lcrr}
\hline \multirow{2}{*}{ Kriteria Investasi } & Wanamina Pola 60:40 & Wanamina Pola 50:50 & non wanamina \\
\cline { 2 - 4 } & Max turun 29\% & Max turun $19,2 \%$ & Max turun $12,5 \%$ \\
\hline NPV & $(95.887)$ & $(95.190)$ & $(265.956)$ \\
Net B/C & 1,0 & 1,0 & 1,0 \\
IRR & $18,9 \%$ & $18,9 \%$ & $18,8 \%$ \\
PP & 7,3 & 7,1 & 7,0 \\
\hline
\end{tabular}

Sumber : Analisis Data Primer, 2014

Hasil analisis switching value tersebut dapat dilihat bahwa batas maksimal perubahan terhadap penurunan produksi pada tambak wanamina lebih besar dibanding pada tambak non wanamina. Apabila perubahan yang terjadi melebihi batas tersebut, maka usaha budidaya tambak bandeng-udang windu menjadi tidak layak atau tidak menguntungkan. Besarnya penurunan produksi pada tambak wanamina pola 60:40 adalah maksimal sebesar 29\% menunjukkan bahwa usaha ini masih layak apabila penurunan yang terjadi terhadap produksi tidak lebih besar dari 29 persen. Untuk tambak non wanamina, sangat sensitif terhadap penurunan produksi, hal ini ditunjukkan dengan nilai maksimal sebesar $13,5 \%$, artinya para petani tambak harus menjaga agar tidak terjadi penurunan produksi melebihi 13,5\% karena usaha ini akan merugi dan menjadi tidak layak.

Hasil analisis sensitivitas bila terjadi kenaikan harga input pupuk, yaitu para petani tambak membeli pupuk non subsidi dengan harga tiga kali lipat dari harga pupuk bersubsidi, seperti pada tabel berikut:

Tabel 9. Sensitivitas kenaikan biaya pupuk dan kenaikan biaya operasional pada Analisis Finansial Usaha Perikanan Tambak Bandeng - Udang Windu

\begin{tabular}{lrrr}
\hline Kriteria Investasi & Wanamina Pola 60:40 & Wanamina Pola 50:50 & non wanamina \\
\hline kenaikan biaya pupuk akibat pembelian pupuk non subsidi & & \\
\hline NPV & 36.605 .229 & $19.257,059$ & 8.872 .074 \\
Net B/C & 1,8 & 1,5 & 1,2 \\
IRR & $37,5 \%$ & $29,4 \%$ & $24,2 \%$ \\
PP & 3,6 & 5,3 & 5,7 \\
\hline switching value biaya & naik max $69,4 \%$ & naik max $38,6 \%$ & naik max $22,5 \%$ \\
\hline NPV & 29.687 & $(17.574)$ & $(392.570)$ \\
Net B/C & 1,0 & 1,0 & 1,0 \\
IRR & $11,5 \%$ & $19,0 \%$ & $18,8 \%$ \\
PP & 2,2 & 4,7 & 4,7 \\
\hline
\end{tabular}

Sumber : Analisis Data Primer, 2014

Penggunaan pupuk urea dan TSP untuk menumbuhkan pakan alami di tambak. Jumlah penggunaan pupuk tergantung dari jumlah luasan kolam tambak. Pupuk diberikan di awal kegiatan sebelum masuknya bibit nener dan benur, juga diberikan pada saat pemeliharaan dengan sebelumnya dilihat terlebih dahulu 
pertumbuhan dan kemelimpahan klekap sebagai pakan alami. Para petani tambak dapat membeli pupuk urea dan TSP bersubsidi yang harganya sangat murah dibandingkan harga pupuk non subsidi. Tingginya kebutuhan akan pupuk bersubsidi di sektor pertanian seringkali menyebabkan kelangkaan, sehingga para petani tambak yang berusaha di sector perikanan terpaksa harus membeli pupuk non subsidi yang harganya hampir tiga kali lipat pupuk bersubsidi. Pembelian pupuk non subsidi ini akan meningkatkan biaya operasional usaha tambak rakyat ini.

Hasil analisis menunjukkan usaha perikanan tambak polikultur ini tetap layak diusahakan pada semua pola tambak, meskipun terjadi kelangkan pupuk bersubsidi, dan petani tambak terpaksa membeli pupuk non subsidi dengan harga lebih tinggi, yang pada akhirnya terjadi penurunan nilai NPV dari keadaaan normal, dan tingkat pengembalian modal yang lebih lama pada setiap pola tambak.

Hasil analisis switching value menunjukkan batas maksimal rentang perubahan terhadap kenaikan biaya operasional pada tambak wanamina lebih besar dibanding pada tambak non wanamina. Apabila perubahan yang terjadi melebihi batas tersebut, maka usaha budidaya tambak bandeng-udang windu menjadi tidak layak atau tidak menguntungkan. Kenaikan biaya operasional pada tambak wanamina pola 60:40 adalah maksimal sebesar 69,4\% menunjukkan bahwa usaha ini masih layak apabila penurunan yang terjadi terhadap produksi tidak lebih besar dari 69,4 persen, sedangkan untuk tambak pola 50:50 kenaikan biaya operasional yang diperbolehkan maksimal sebesar 38,6\%. Untuk tambak non wanamina, sangat sensitif terhadap kenaikan biaya operasional, hal ini ditunjukkan dengan nilai maksimal sebesar $24,7 \%$, artinya para petani tambak harus menjaga agar tidak terjadi kenaikan biaya operasional melebihi $24,7 \%$ karena usaha ini akan merugi dan menjadi tidak layak.

\section{KESIMPULAN}

Berdasarkan kriteria indikator analisis kelayakan finansial, usaha perikanan tambak polikultur bandeng - udang windu di Kecamatan Pemangkat, Jawai, dan Jawai Selatan Kabupaten Sambas layak diusahakan. Usaha budidaya di Kecamatan Pemangkat dengan penerapan tambak wanamina pola 60:40 (60\% lahan ditanami mangrove dan $40 \%$ lahan kolam tambak) memberikan nilai NPV tertinggi sebesar 40.492.764, Net B/C sebesar 1,9, dan IRR 39,5\%, dengan pengembalian investasi selama 3,6 tahun.

Hasil analisis sensitivitas untuk penurunan jumlah produksi bandeng sebesar $40 \%$ dan udang windu sebesar $60 \%$ akan menyebabkan usaha dengan semua pola tambak menjadi tidak layak. Jika terdapat kenaikan biaya pupuk, untuk usaha perikanan polikultur dengan semua pola tambak saat ini masih layak. Berdasarkan analisis switching value untuk kenaikan biaya operasional maksimal sebesar $69,4 \%$; 38,6\%, dan $24,7 \%$ masing-masing untuk pola tambak 60;40 ; 50:50; dan tambak non wanamina

\section{DAFTAR PUSTAKA}

Budihastuti, Rini. 2013.Pengaruh Penerapan Wanamina Terhadap Kualitas Lingkungan Tambak dan Pertumbuhan Udang di Kota Semarang. 
Prosiding Seminar Nasional Pengelolaan Sumberdaya Alam dan Lingkungan 2013 ISBN 978-602-17001-1-2 374

Departemen Kehutanan dan Perkebunan, 1999. Strategi Nasional Pengelolaan Hutan Mangrove di Indonesia. Direktorat Jenderal Reboisasi dan Rehabilitasi Lahan, Jakarta.

Gittinger, J.P. 1982. Economic Analysis of Agricultural Project, Baltimore, John Hopkins University Press

Hastuti RB. 2010. Penerapan wanamina (Sivofishery) Berwawasan Lingkungan di Pantai Utara Kota Semarang. Jurnal Lingkungan Tropis Vol 5 no 1 Maret 2010

Kholifah, Umy, Ninis Trisyani, Is Yuniar. 2008. Pengaruh Padat Tebar yang Berbeda terhadap Kelangsungan Hidup dan Pertumbuhan pada Polikultur Udang Windu (Penaeus Monodon Fab) dan Ikan Bandeng (Chanos Chanos) pada Hapa di Tambak Brebes - Jawa Tengah. Neptunus Vol 4 No. 2 Januari 2008.152-158.

Kusmana, C. 1997. Ekologi danSumberdaya Ekosistem Mangrove.Jurusan Manajemen Hutan Fakultas

Kehutanan IPB. BogorMaie, N., O. Pisani, R. Jaffe, 2008, Mangrove Tannins in Aquatic Ecosystems: Their Fate and Possible Influence on Dissolved Organic Carbon and Nitrogen Cycling, Limnol. Oceanogr. 53(1): 160 171

Mardiyati, S, 2004, Optimasi Usahatani Tumpangsari Empang Parit di Lahan Konservasi Hutan Mangrove RPH Cikiperan BKPH Rawa Timur KPH Banyumas Barat, Tesis, Program Pasca Sarjana, UGM, Yogyakarta.

Musiran, 2007., Kajian Hubungan Tambak Wanamina (Sylvofishery) terhadap produksi Udang Windu (Penaeus Monodon Fabr). Studi Kasus di Kecamatan Kubu kabupaten Pontianak Kalimantan Barat. Tesis. Magister Budidaya perairan, fakultas perikanan dan Kelautan, Universitas Brawijaya, Malang

Poedjirahajoe, E., 2000, Pengaruh Pola Sylvofishery terhadap Pertambahan Berat Ikan Bandeng (Chanos chanos Forskal) di Kawasan Mangrove Pantai Utara Kabupaten Brebes,Jurnal Konservasi Kehutanan 2: 109-124

Pramudji, 2004. Penanganan Hutan Mangrove di Kawasan Pesisir Indonesia: Suatu program yang sangat mendesak. Oseana, Volume XXIX, Nomor 1, Tahun $2004: 19-26$

Primavera J. H., J. M. A. Esteban, 2008, A Review of Mangrove Rehabilitation in the Philippines: Successes, Failures and Future Prospects, Wetlands Ecology and Management 16: 345 - 358

Sevilla, C.G., et, al. 1993. Pengantar Metode Penelitian, Jakarta; Penerbit Universitas Indonesia (UI-Press)

Shimoda, T., E. Suryati, T. Ahmad, 2006, Evaluation in A Shrimp Aquaculture System Using Mangrove, Oyster and Seaweed as Biofilters Based on the Concentrations of Nutrients and Chlorophyll a, JARQ 40(2): 189 - 193 
Syahid, M. Subhan, A. dan Armando, R. 2006. Budidaya Udang Organik Secara polikultur. Penebar swadaya: Jakarta

Tjoronge, M. 2005. Polikultur Rumput Laut Gracillaria sp. dan Ikan Bandeng (Chanos chanos) Dengan Padat Penebaran Yang Berbeda. Jurnal Penelitian Perikanan Indonesia. Departemen Kelautan dan Perikanan. 11

Vaiphasa, C., W. F. de Boer, A. K. Skidmore, S. Panitchart, T. Vaiphasa, N. Bamrongrugsa, P. Santitamnont, 2007, Impacts of Shrimp Pond Waste Materials on Mangrove Growth and Mortality: A Case Study from Pak Phanang, Thailand,Hydrobiologia 591:47 - 57

Warsito, S. P.1995. Analisis finansial dan ekonomi dalam penyusunan perencanaan pengusahaan hutan. Fakultas Kehutanan UniversitasGadjahMada. Yogyakarta 